\title{
Developing Online Learning Oriented Learning Devices to Improve Mathematic Abstraction and Self-Efficacy Abilities Istiqlal Delitua Junior High School VII Class Student
}

\author{
Elidar Tanjung', Izwita Dewi², Mulyono ${ }^{3}$ \\ ${ }^{1}$ Postgraduate Program in Department of Mathematic Education, Universitas Negeri Medan, Indonesia \\ ${ }^{2,3}$ Universitas Negeri Medan, Indonesia \\ elidar@unimed.ac.id,dewi_lubis62@yahoo.co.id
}

\begin{abstract}
This research is a development research conducted at SMP Istiqlal Delitua which aims to find out how; 1) the level of validity, effectiveness and practicality of learning tools developed in improving students' mathematical abstraction abilities and self-efficacy; 2) Increasing students' mathematical abstraction abilities and selfefficacy in implementing online learning-oriented learning tools. This study produces an online learning-oriented learning tool which is carried out in accordance with the Dick \& Carey development model procedure. The results of this study are the learning tools developed; 1) valid, both content and construct validity, 2) practical, seen from the validator's assessment and teacher's observation in managing learning, 3) effective, seen from the completeness of learning, student responses and learning time; 4) improvement of students' mathematical abstraction ability; 5) increased student self-efficacy in the high category.
\end{abstract}

Keywords device development; learning online; mathematical abstraction; student self-efficacy

\section{Introduction}

Education is a necessity for all society, but in its implementation it is often faced with various problems. One of the problems that often occur in the world of Indonesian education is the problem of learning.

Sanjaya (2006) states that one of the problems faced by our education world is the problem of the weakness of the learning process. Including mathematics learning, because learning mathematics is considered difficult by students. The difficulty in learning mathematics is not solely due to the mathematics subject matter itself, but also due to the ineffective ability of the teacher to manage mathematics learning. Where in the learning process, the strategies applied by the teacher are generally less varied and do not involve students in the learning process.

The world in general and Indonesia in particular, is entering a new industrial era in the 21 st century which is marked by the era of digitization in various sectors of life. Experts call this the era of the industrial revolution 4.0. In facing this industrial revolution, technology and information have become the basis of human life. The change in civilization to a knowledge society (knowledgesociety) requires the world community to master 21 st century skills, namely being able to understand and utilize information and communication technology (ICT Literacy Skills). Education plays a very important and strategic role in building a knowledgeable society that has the skills: (1) literacy in technology and media; (2) communicate effectively; (3) critical thinking; (4) solving problems; and (5) collaborating. 
After the Covid-19 pandemic entered Indonesia which then in mid-March 2020 to reduce the number of Covid 19 sufferers, the provincial and local governments produced policies in the world of education, namely temporarily eliminating face-to-face learning and replaced with online learning at both the school and college levels. In (Adijaya, 2018) it is said that online learning or virtual learning is considered a new paradigm in the learning process because it can be done in a very easy way without having to meet face to face in a classroom and only relying on an internet connection-based application so the learning process can take place. Online learning is a type of learning process that relies on an internet connection to carry out the learning process. Several studies have shown that online learning models have an influence on the achievement of student learning outcomes. The above says that learning begins with the presentation of a contextual problem. By presenting the problems often faced by students in everyday life with the guidance of the teacher through the teaching and learning process by presenting contextual problems.

Learning tools are very important for teachers and for students. According to Nur and Aswin (2012), learning devices facilitate and assist teachers in preparing and implementing teaching and learning activities in class. Teachers will not be able to teach effectively and efficiently without learning tools, nor will students be able to adjust to learning without supporting learning tools. The reasons for the importance of learning tools according to Wahyudi (2014: 35) are: 1) as a learning guide, 2) as a minimum standard for teacher work, 3) improving teacher performance, 4) teacher performance evaluation tools. So that with complete teacher learning tools, they can see the performance they are doing. Therefore, learning tools are very important to be developed.

From the observations, the reality and condition of the teachers at SMP Istiqlal Medan, it turns out that the teachers are still not able to arrange learning tools properly, this is because the teacher's understanding in arranging learning tools is still lacking. Teachers at SMP Istiqlal are required to prepare learning tools, but the tools that have been compiled are not validated, so they are not yet effective for use.

Textbooks are intended for teachers and students. Teaching materials (books that will be made contain activity-based learning plans and contain learning sequences that are stated in the activities that students must do. This book directs to things that students must do with teachers and classmates to achieve certain competencies, not books whose material is only read, filled out or memorized.

From the observations of the textbooks used, the material begins with a formula given, then an example problem. Teaching is not in accordance with the 2013 curriculum, namely the scientific approach that starts with observing real problems, is followed up by asking questions, exploring, associating, and ending with communicating them. The printed books used are still less attractive so that students feel less attractive so that students feel less interested in reading and studying the book.

To support learning other than textbooks, student worksheets are a supporting component of learning. According to Trianto (2011), student activity sheets are student guides used to carry out investigative activities or problem-solving abilities. This activity sheet is a guide for cognitive development exercises as well as a guide for the development of all aspects of learning. Student activity sheets contain a set of basic activities that must be done by students to maximize understanding in an effort to form basic abilities in accordance with the indicators of achievement of learning outcomes that must be taken. Meanwhile, the use of LAS is still recommended by schools made by publishers whose contents refer to the material summary and a collection of questions. 
The ability of mathematical abstraction is the ability to find solutions to mathematical problems without the real object of the problem being present. The ability of mathematical abstraction is very important because with the ability of mathematical abstraction students can describe mathematical concepts in a mathematical problem or in other words can build a model of a problem, students can also identify the characteristics of objects by making direct observations or with the experiences they get..

However, the facts in the field show that students' mathematical abstraction abilities are still low. In addition to the cognitive abilities that students must have, affective abilities are also important for students to have. Because affective ability is a supporting ability so that Indonesian education can be better.

It is known that one of the factors of student success is internal factors and one of them is Self-Efficacy. Belief in one's inner abilities is very necessary in order to compete in the era of globalization and the world of work. With students having high self-efficacy, it makes students motivated to solve problems related to mathematical abstraction.

The reality in the field based on the results of interviews with SMP Istiqlal Medan teachers shows that junior high school (SMP) mathematics teachers rarely pay proportional attention to increasing student self-efficacy. When the researcher directly asked several seventh grade students of SMP Istiqlal Medan, when the lesson was taking place, students still felt less confident about expressing their opinions and generally would only answer questions when appointed by the teacher. This makes the self-efficacy of SMP Istiqlal Medan students still low.

\section{Review of Literatures}

\subsection{Learning Tools}

Majid (2011: 18) says that: "Learning tools are all forms of materials used to assist teachers / instructors in carrying out teaching / learning activities". Ririn (2020) states that the learning process is influenced by the environment, including students, teachers, modules, magazines, interactive learning media and various other learning resources. Learners succeed in learning if from themselves they have the desire and enthusiasm to learn (Ritonga, 2020). Learning tools are information, tools and texts needed by teachers for planning and studying the implementation of learning. Learning devices are all forms of material used to help teachers carry out teaching and learning activities.

Hidayat (in Majid, 2011: 21) states that: learning tools that must be prepared in learning planning include:

a. Understand the curriculum

b. Mastering teaching materials

c. Develop a teaching program

d. Carry out a teaching program

e. Assessing the teaching program and the results of the teaching and learning process that has been implemented.

\subsection{Development of Learning Tools}

According to Rahman and Amri (2013: 207) say that "developing learning tools is a series of processes or activities carried out to produce a learning device based on existing development theories. So the development of learning tools is a process carried out to produce a series of learning tools used by teachers and students in the learning process in the classroom. However in this study, the development of learning tools to be developed is llimited to (a) Teacher Book (BG). 
However, in this study, the development of learning tools to be developed is limited to (a) Teacher Books (BG), Student Books and (b) Student Worksheets (LKPD).

\subsection{Quality of Learning Tools}

Nieveen (2007:93) menyatakan "First of all, it is necessary to make clear the type of value judgment that the evaluation needsto result in. in this respect, we distinguish for quality criteria that are applicable to a wide of educational interventions".

The above opinion has the meaning that first of all, it is necessary to explain the kind of value judgments that the evaluation needs to produce. In this respect, we distinguish four quality criteria that apply to a variety of teacher interventions. The four criteria include; (1) Relevance (content validity); (2) Consistency (construct validity); (3) practicality; and (4) effectiveness.

\subsection{Mathematical Abstraction}

Gery \& Tall (2007) argue that abstraction is a process of describing a certain situation in a concept that can be thought of through a construction. This situation is in the form of concepts in mathematics which are then translated into symbols and images. According to him, the abstraction process occurs in several circumstances, but there are three situations that can lead to the abstraction process in the mathematics learning process. The first situation can arise when individuals focus their attention on the characteristics of the objects they receive, and then give names through a process of classification based on categories into a group. The second state, when focusing attention on the actions applied to objects that lead to symbols is then manipulated. The third situation occurs when compiling a collection of theories about the concept to form a concept that can be thought through a series of mathematical proofs.

According to Piaget, reviewed by Dubinsky (Tall, 2002), a person's knowledge is an abstraction of an object or thing. Piaget distinguished that there are three types of abstraction, namely: empirical abstraction (Pseudo-empirical abstraction), reflective abstraction (reflective abstaction). Empirical abstraction, in empirical abstraction the individual obtains knowledge of the properties of objects; Pseudo-empirical abstraction (pseudo-empirical abstraction), all empirical abstraction is the middle between empirical abstraction and reflective abstraction and disturbs the nature that the subject introduces to the object; Reflective Abstraction, is a concept introduced by Piaget (Tall, 2002) to explain the construction of a person's mathematical logic structure in cognitive development when studying a concept.

Mitchelmore \& White (2007), broadly distinguish two abstractions, namely empirical abstraction and theoretical abstraction. Empirical abstraction is the process of forming an understanding of an abstract object based on empirical experience. One example is the abstraction concept presented by Skemp and the empirical abstraction concept presented by Piaget (Mitchelmore \& White, 2007). Theoretical abstraction consists of forming concepts to suit several theories. Vygotsky (Michelmore \& White, 2007) distinguishes between the meanings of concepts in the context of everyday life with the meaning of concepts in the context of the scientific field.

The indicators of the abstraction process according to Wiryanto (2014) can be observed from the following activities:

(1) Identifying the characteristics of the object through direct experience.

(2) Identifying the characteristics of the object being manipulated or imagined.

(3) Make generalizations.

(4) Represent mathematical ideas in terms and mathematical symbols. 
(5) Releasing material characteristics from an object or doing idealization.

(6) Creating relationships between processes or concepts to form a new understanding.

(7) Apply the concept to the appropriate context.

(8) Manipulating abstract mathematical objects.

Meanwhile, according to Michelmore \& White (1995) abstraction is generated based

on 3 steps, namely: (1) recognizing similarities and ignoring differences, (2) recognizing concepts that contain these similarities, and (3) changing the concept into an object in its own sense.

\subsection{Self-Efficacy Ability}

Self-efficacy is one of the most influential aspects of self-knowledge or selfknowledge in everyday human life. This is because the self-efficacy that is owned influences the individual in determining the actions to be taken to achieve a goal including the estimation of various events to be faced. Baron and Byrne define self-efficacy as a person's evaluation of their ability or competence to perform tasks, achieve goals, and overcome obstacles. Bandura and Woods explain that self-efficacy refers to the belief in an individual's ability to drive motivation, cognitive abilities, and actions needed to meet the demands of the situation (in Ghufron), 2014: 74).

According to Bandura (in Ghufron, 2010: 88), self-efficacy in each individual will differ from one individual to another based on three dimensions, namely the level dimension (level), the dimension of strength (strength), and the dimension of generalization (generality).

\subsection{Online Learning}

a. E-learning

Online Learning (direct learning) according to Michael Molinda (2005: 182) can be defined as an effort to connect learners (learners) with learning resources (databases, experts / instructors, libraries) that are physically separated or even far apart but can communicate with each other, interact or collaborating (directly / synchronously and indirectly / asynchronously) .."

Online Learning (direct learning) according to Michael Molinda (2005: 182) can be defined as an effort to connect learners (learners) with learning resources (databases, experts / instructors, libraries) that are physically separated or even far apart but can communicate with each other, interact or collaborating (directly / synchronously and indirectly / asynchronously).

This online activity is included in an individual learning model. Online Learning is very potential because students and teachers can access material widely from various sources. The ILRT of Bristol University (2005) defines online learning as the use of electronic technology to deliver, support and enhance teaching, learning and assessment. Udan and Weggen (2000) state that online learning is part of distance learning while online learning is part of e-learning. In addition, the term e-learning includes various applications and processes such as computer-based learning, web-based learning, virtual classrooms, etc ; meanwhile, on-line learning is part of technology-based learning that utilizes Internet, intranet and extranet resources.

\subsection{Learning Device Development Model}

The learning model that is often used in broad research and development is the systems approach model designed and developed by Dick \& Carey. There are ten steps of the Dick \& Carey model (Dick \& Carey, 2009), namely: (1) Identify Instructional Goal (s) (Identify Learning Objectives), (2) Conduct Instructional Analysis (Conducting 
Instructional Analysis), (3) Analyze Learnes and Contexts (Analyzing Knowledge and Context), (4) Write Performance Objectives (Formulating Performance Objectives), (5) Develop Assessment Instruments, (6) Develop Instructional Strategy, (7) Develop and Select Instructional Materials (Developing and Selecting Learning Materials), (8) Design and Conduct Formative Evaluation of Instruction (Designing and Implementing a Formative Evaluation of Learning), (9) Revising Instructions, (10) Design and Conduct Summative Evaluation (Designing and Implementing Summative Evaluation).

\section{IIII. Research Method}

This type of research is a Research and Development (Research Development). In this study, researchers developed student books and worksheets for online learningoriented students. This research will be conducted at SMP Istiqlal Deli Tua, which is located on Jalan Besar Deli Tua, North Sumatra. Research time is the odd semester of the 2020/2021 school year. The subjects in this study were seventh grade students of SMP Istiqlal Deli Tua, while the objects in this study were student worksheets and students 'mathematical abstraction ability test instruments and students' self-efficacy on number material developed by online learning.

\subsection{Procedure for Developing Student Worksheets and Test Instruments}

The development of teaching materials used in this study is the Dick \& Carey development model for several reasons, namely: the Dick \& Carey model has been widely used to develop effective tools, every step of the Dick \& Carey model there is feedback or revision, the model steps Dick \& Carey is very concise, concise and clear and relates to one another and according to the applicable curriculum.

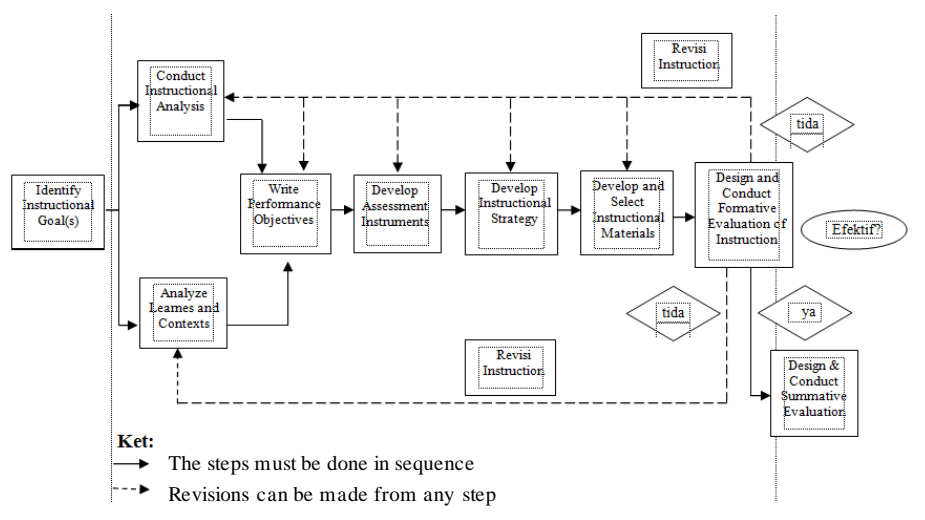

Figure 1. Learning Design Model by Dick \& Carey (Dick, Carey \& Carey, 2009)

\subsection{Identification of Learning Objectives}

The initial stage of this model is to identify learning objectives, the goal is to determine the competencies that are expected to be mastered and carried out by students after learning. This objective is determined from the analysis of the implementation of learning, from the tests given, and from the various learning difficulties of students.

The process of identifying learning objectives to be achieved in the learning process starts from: 1) identifying learning objectives contained in the applicable curriculum. 2) identify the initial characteristics of students, 3) determine the learning objectives by considering the characteristics of the students and the applicable curriculum. 


\section{a. Instructional Analys is}

Activities in instructional analysis are determining what is needed to achieve learning objectives. To achieve the identified learning objectives, there are several things that must be done, including the selection of the approach used in the learning process, the tests given, and the teaching materials used.

\section{b. Knowledge and Context Analysis}

Apart from analyzing learning, knowledge and context are also analyzed. Knowledge analysis is conducted to determine the extent to which students have mastered the skills or knowledge so that they can participate in these learning activities.

In addition to analyzing student knowledge, student characteristics need to be analyzed for learning design purposes. These student characteristics are the characteristics of students before participating in learning. The technique used in identifying student characteristics is observation.

Besides analyzing students' knowledge, context analysis also needs to be analyzed. Context analysis is a description of the extent to which material can be used to provide the necessary expertise.

\section{c. Formulation of Objectives}

Based on instructional analysis and statements about students' initial behavior, specific statements will be formulated about what students should be able to do after completing learning. These statements are derived from the skills identified in the learning analysis, identifying the skills to be learned, the conditions under which the skills will be demonstrated, and the performance success criteria.

\section{d. Development of Assessment Instruments}

Based on the formulated objectives, an assessment item was developed to measure students' abilities as predicted in the objectives. In this study, the test developed was a test of students' mathematical abstraction ability and self-efficacy. Once compiled, the test is then validated by experts, focused on content, language and question writing.

\section{e. Learning Strategy Development}

Based on the five previous stages, then the learning model will be identified that will be used to achieve learning objectives. The learning model used is an online learning model. Online learning is a form of distance learning / training that utilizes telecommunications and information technology which aims to help students master the subject matter better. So online means learning using electronic device assistance services directly.

\section{f. Development and Selection of Learning Devices}

At this stage, learning tools are selected to be developed. Learning tools to be developed are problematic learning tools. Learning equipment is considered a problem because it does not exist, or exists but does not meet the learning needs, or exists but needs to be repaired, and so on. In this study, the learning tools to be developed were student activity sheets and tests to measure students' mathematical abstraction abilities and selfefficacy. 


\section{g. Design and Implementation of Learning Formative Evaluation}

The formative evaluation used in the development of this teaching material is oneon-one evaluation by experts and field trials. In the one-on-one evaluation stage, teaching materials and research instruments are validated by experts in their fields and practitioners. The experts referred to in this case are competent validators including UNIMED mathematics education lecturers and practitioners including mathematics teachers, in general expert validation includes content validation containing observation points related to: (1) format; (2) language; and (3) content. The results of expert validation are in the form of validation values, corrections, criticisms, and suggestions which are used as the basis for revising and improving the developed teaching materials. The revised teaching materials are teaching materials that have met the valid criteria. After the results of validation by experts and practitioners are obtained, corrections are made based on considerations of correction, criticism, and suggestions given by the validator.

The field trial phase with a large group was called the I trial. The trial of this teaching material was carried out at the research location, namely Istiqlal Middle School. Trial I was conducted in class VII-I which consisted of 40 students. The lessons that were carried out in each trial I were three meetings. In this trial, what will be seen is the effectiveness of teaching materials.

\section{h. Revision of Teaching}

The final step in the design and development process is to revise instructions. Based on the results of the validation on formative evaluation, the parts that need to be fixed or revised, at this stage the researcher makes improvements or revisions to the learning materials according to the suggestions of the validators.Pendesainan dan Pelaksanaan Evaluasi Sumatif

In this stage implementation is carried out on a wider scale in schools and requires very careful preparation and a very long time. After being implemented, a summative evaluation is carried out, the goal is to see whether the new product is more effective than the old one from each school to solve existing problems and then determine which product is more effective to use.

1). Trial Design

The trial design used in the development of the instrument was the One - group pretest posttest design. As follows:

Keterangan:

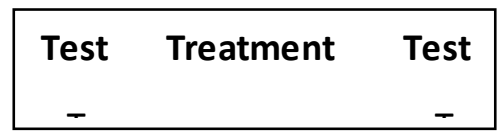

$\mathrm{T}_{1} \quad$ : Pre-test

$\mathrm{T}_{2} \quad$ : Post-test

$\mathrm{X} \quad$ : Treatment dengan perangkat pembelajaran melalui pembelajaran online

\subsection{Instruments and Data Collection Techniques}

To measure the validity and effectiveness of mathematics learning tools, a research instrument was compiled and developed.

All validation sheets in this study were used to measure the validity of the learning tools and instruments needed. Some of the validation sheets used include: a) Teacher Book validation sheets (BG); (b) Student Book validation sheet (BS), and c) Student Worksheet Validation Sheet (LKPD). This validation sheet contains the components that are assessed including: format, language, illustrations, and content. Indicators of each component. 
Table 1. The Validation Results of Lesson Plan

\begin{tabular}{|c|l|c|c|}
\hline No. & \multicolumn{1}{|c|}{ Rated Aspect } & Average Each Aspect & Category \\
\hline 1 & Format & 4,05 & Valid \\
\hline 2 & Language & 4,06 & Valid \\
\hline 3 & Contents & 4,00 & Valid \\
\hline \multicolumn{2}{|c|}{ Average } & 4,04 & Valid \\
\hline
\end{tabular}

\section{a.Observation Sheet of the Teacher's Ability to Manage Learning}

This assessment sheet is used to measure the feasibility of learning tools based on theoretical mastery and experience of experts and practitioners. Based on mastery of theory and experience, observations are made during learning (from the beginning of learning to the end of learning) and observations are made by 2 observers.

The observer writes down the assessment categories that appear. The categorization of the learning management teacher's ability consists of five assessment criteria, namely very bad (score 1), not good (score 2), good enough (score 3), good (score 4), and very good (score 5).

\section{b. Data Analys is Techniques}

This research is a development research, the product of this development research is an online learning-oriented learning tool. The purpose of data analysis in this study is used to determine the quality of student activity sheets and test instruments produced in valid, practical and effective qualifications.

\section{Results and Discussion}

This research is a development research which produces a learning tool that meets the criteria of validity, practicality and effectiveness. Learning tools developed include; a) Teacher's Book validation sheet (BG); (b) Student Book Validation Sheet (BS), and c) Student Worksheet Validation Sheet (LKPD). Learning tools were developed using the development model Dick \& Carey, et al. Which includes ten stages, namely (1) Identify Instructional Goal (s) (Identification of Learning Objectives), (2) Conduct Instructional Analysis (Conducting Instructional Analysis), (3) Analyze Learnes and Contexts (Analyze Knowledge and Context), (4) Write Performance Objectives (Formulating Performance Objectives), (5) Develop Assessment Instruments, (6) Develop Instructional Strategy (Developing Learning Strategies), (7) Developing and Select Instructional Materials, (8) ) Design and Conduct Formative Evaluation of Instruction (Designing and Implementing Formative Evaluation of Learning), (9) Revising Instructions, (10) Designing and Conduct Summative Evaluation (Designing and Implementing Summative Evaluations) Each stage is carried out on an ongoing basis.

The results of expert validation have values of validation, correction, criticism, and suggestions which are used as a basis for revising and improving learning devices. The revision result learning device is a learning device that has met the valid criteria. Validator assessment data on the learning plan can be seen in the Appendix which supports the research. In making revisions, the researcher refers to the results of the discussion by following the validator's suggestions and instructions. The average value of the indicators for each aspect of the assessment of the validity of the lesson plans for each expert and practitioner is presented in the following table: 
Average indicator values in Table 1 obtained from the results for the number of indicator values for each aspect given by each expert and practitioner with the number of indicators on that aspect. The aspect value is obtained from the results for the average number of indicator values given by experts and practitioners for each aspect of the assessment with the number of experts and practitioners as assessors. Furthermore, the Va value or the total aspect average value is 4.04 . This value is obtained from the results for the number of aspects value with the number of aspects of the validity assessment of the content of the lesson plan. Va value is 4.04 if it is referred to the criteria for determining the level of validity of learning devices that have been previously defined in Chapter III, it is concluded that the learning implementation plan meets the validity criteria with the valid category and can be used with minor revisions.

The average value of the indicators for each aspect of the assessment of the validity of the teacher's books from each expert and practitioner is presented in the following table:

Table 2. The Validation Results of Teacher's Book

\begin{tabular}{|c|l|c|c|}
\hline No. & Rated Aspect & Average Each Aspect & Category \\
\hline 1 & Format & 4,6 & Valid \\
\hline 2 & Language & 4,45 & Valid \\
\hline 3 & Illustration & 4,5 & Valid \\
\hline 4 & Contents & 4,6 & Valid \\
\hline \multicolumn{2}{|c|}{ Average } & 4,53 & Valid \\
\hline
\end{tabular}

Based on table 2, it can be seen that the teacher's book average value is 4.53. Furthermore, this value is designated in the validity criteria set out in Chapter III. So referring to these criteria, it can be concluded that the BG developed meets the validity criteria with the "valid" category. The five validators concluded that the teacher's book could be used with minor revisions. For suggestions for improvement, several writing/spelling errors in the manuscript have been corrected according to the validator's strokes.

The average value of the indicators for each aspect of the assessment of the validity of the student books of each expert and practitioner is presented in the following table:

Table 3. The Validation Results of Students' Book

\begin{tabular}{|c|l|c|c|}
\hline No. & Rated Aspect & Average Each Aspect & Category \\
\hline 1 & Format & 4,54 & Valid \\
\hline 2 & Language & 4,45 & Valid \\
\hline 3 & Illustration & 4,35 & Valid \\
\hline 4 & Contents & 4,6 & Valid \\
\hline \multicolumn{2}{|c|}{ Average } & 4,48 & Valid \\
\hline
\end{tabular}

Based on table 3 it can be seen that the average value of BS validation is 4.48. Furthermore, this value is referred to in the validity criteria set in Chapter III. So referring to these criteria, it can be concluded that the BS developed meets the validity criteria with the "valid" category. The five validators concluded that student textbooks could be used with minor revisions. For suggestions for improvement, several writing / spelling errors in the manuscript have been corrected according to the validator's strokes.

Expert and practitioner assessment data on Student Worksheet (LKPD) can be seen in the supporting Appendix. The average value of the indicators for each aspect of 
evaluating the validity of the students' books from each expert and practitioner is presented in the following table.

Table 4. The Validation Results of Students' Worksheet

\begin{tabular}{|c|l|c|c|}
\hline No. & Rated Aspect & Average Each Aspect & Category \\
\hline 1 & Format & 4,07 & Valid \\
\hline 2 & Language & 4,11 & Valid \\
\hline 3 & Contents & 4,03 & Valid \\
\hline \multicolumn{2}{|c|}{ Average } & 4,07 & Valid \\
\hline
\end{tabular}

From Table 4, seen the average value of the LKPD validation of 4.07. Furthermore, this value is referred to in the validity criteria set in Chapter III. So referring to these criteria it can be concluded that the developed LKPD meets the validity criteria with valid categories and can be used with minor revisions.

From the validators' assessment, corrections, criticisms, and suggestions were obtained which were used as material for consideration in revising the LKPD. For suggestions for improvement, several writing / spelling errors in the manuscript have been corrected according to the validator's strokes.

Based on the results of the validation by the expert, it was concluded that the instruments to be used in this study were feasible to use. The assessment of mathematical abstraction abilities is presented in the following table:

Table 5. Validation Result of Students' Mathematical Abstraction Ability Test

\begin{tabular}{|c|l|c|c|c|c|}
\hline \multirow{2}{*}{ No } & \multirow{2}{*}{ Validator } & \multicolumn{4}{|c|}{ Validator's Assessment for Each } \\
Question Item
\end{tabular}

Table 6. The Students' Self-efficiacy of Validation Results in Each

\begin{tabular}{|c|c|c|c|c|c|c|c|c|c|c|c|c|c|c|c|c|}
\hline \multirow{2}{*}{ No } & \multirow{2}{*}{ Validator } & \multicolumn{15}{|c|}{ Validator's Assessment for Each Question Item } \\
\hline & & 1 & 2 & 3 & 4 & 5 & 6 & 7 & 8 & 9 & 10 & 11 & 12 & 13 & 14 & 15 \\
\hline 1 & Validator 1 & TR & TR & TR & TR & RK & TR & TR & TR & TR & TR & TR & TR & TR & TR & $\mathrm{TR}$ \\
\hline 2 & Validator 2 & TR & TR & TR & TR & TR & TR & TR & TR & TR & TR & TR & TR & TR & TR & $\mathrm{TR}$ \\
\hline 3 & Validator 3 & TR & $\mathrm{TR}$ & TR & TR & $\mathrm{TR}$ & TR & TR & TR & TR & TR & TR & TR & TR & TR & $\mathrm{TR}$ \\
\hline 4 & Validator 4 & TR & TR & RK & TR & TR & TR & TR & TR & TR & TR & TR & TR & TR & TR & TR \\
\hline 5 & Validator 5 & TR & TR & TR & TR & TR & TR & TR & TR & TR & TR & TR & TR & TR & TR & $\mathrm{TR}$ \\
\hline
\end{tabular}

\begin{tabular}{|c|c|c|c|c|c|c|c|c|c|c|c|c|c|c|c|c|}
\hline \multirow{2}{*}{ No } & \multirow{2}{*}{ Validator } & \multicolumn{15}{|c|}{ Validator's Assessment for Each Question Item } \\
\hline & & 16 & 17 & $\mathbf{1 8}$ & 19 & 20 & 21 & 22 & 23 & 24 & 25 & 26 & 27 & 28 & 29 & 30 \\
\hline 1 & Validator 1 & TR & TR & TR & TR & RK & TR & TR & TR & TR & TR & TR & TR & TR & TR & TR \\
\hline 2 & Validator 2 & TR & TR & TR & TR & TR & TR & TR & TR & TR & TR & TR & TR & TR & TR & TR \\
\hline 3 & Validator 3 & TR & TR & TR & TR & TR & TR & TR & TR & TR & TR & TR & TR & TR & TR & TR \\
\hline 4 & Validator 4 & TR & TR & RK & TR & TR & TR & TR & TR & TR & TR & TR & TR & TR & RK & RK \\
\hline 5 & Validator 5 & TR & TR & TR & TR & $\overline{T R}$ & $\overline{\mathrm{TR}}$ & TR & $\overline{T R}$ & TR & TR & TR & TR & TR & TR & $\overline{T R}$ \\
\hline
\end{tabular}


Based on table 6 , it can be seen that the five validators provide an assessment of the validity of the content in the student's mathematical abstraction ability test, namely valid, for language and question writing, which is very understandable and understandable. Furthermore, the recommendation is with a small revision, while all the questions in the self-efficacy questionnaire are categorized as valid. These results indicate that all questions and questionnaires can be used and are declared fit for use by the validator.

Based on the results of the analysis of students' answers at the time of the test, data on the mathematical communication skills of class VIIA students were obtained which can be seen in the supporting appendix. The values of students' mathematical abstraction abilities at the pretest and posttest are presented in the following table.

Table 7. Results Description of Students' Mathematical Abstraction Abstraction in Trial II

\begin{tabular}{|c|c|c|}
\hline & $\begin{array}{c}\text { The Result of Pretest } \\
\text { Score }\end{array}$ & $\begin{array}{c}\text { The Result of Postest } \\
\text { Score }\end{array}$ \\
\hline Highest Score & 83,33 & 100 \\
\hline Low Score & 50,00 & 61,11 \\
\hline Average & 66,67 & 80,56 \\
\hline
\end{tabular}

Table 8 shows that the average mathematical abstraction ability of students on the pretest results is 66.67 and the postest results are 80.56. If categorized based on the level of mastery of students, then the level of mastery of students' mathematical abstraction abilities in the results of the posttest II trial can be seen in Table 8:

Table 8. Mastery Level of Mathematical Abstraction Abstraction (Postest) in Trial II

\begin{tabular}{|c|c|c|c|c|}
\hline No. & Score Interval & Total of Student & Precentage & Category \\
\hline 1 & $0 \leq S S<54$ & 0 & $0 \%$ & Very Low \\
\hline 2 & $54 \leq S S<65$ & 3 & $9,375 \%$ & Low \\
\hline 3 & $65 \leq S S<79$ & 11 & $34,375 \%$ & Medium \\
\hline 4 & $79 \leq S S<89$ & 11 & $34,375 \%$ & High \\
\hline 5 & $89 \leq S S<100$ & 7 & $21,875 \%$ & Very High \\
\hline
\end{tabular}

From the results of student learning in the second trial, it is known that there were 3 students $(9,375)$ in the low category, 11 students $(34,375 \%)$ in the moderate category, 11 students $(34,375 \%)$ in the high category, 7 students $(21,875)$ in the very high category. \%) and none of the students got the very low category.

Through the pretest and posttest data, the categories of increase (gain) in the ability of mathematical abstraction can be determined for each student which is determined based on the difference between the pretest and posttest scores to further determine the $\mathrm{N}$-gain value as a result of comparison between gain and maximum gain. The calculation of $\mathrm{N}$ gain on mathematical abstraction ability can be seen in the supporting appendix and is simply represented in table 9 below:

Table 9. Description of Increasing Students' Mathematical Abstraction Abstraction

\begin{tabular}{|c|c|c|c|}
\hline No & N-Gain Range & Category & $\begin{array}{c}\text { Total of } \\
\text { Students }\end{array}$ \\
\hline 1 & $0,7-1,0$ & High & 7 \\
\hline 2 & $0,3-0,69$ & Medium & 16 \\
\hline 3 & $0-0,29$ & Low & 9 \\
\hline & \multicolumn{2}{|c|}{ Total } \\
\hline
\end{tabular}


From the table above, it is known that there has been a significant increase ( $\mathrm{N}$-gain) from the pretest score to the student's posttest score. The table above shows that the number of students in the low category in the second trial was 9 students, for the medium category there were 16 students, for the high category there were 7 students who obtained high n-gain.

In this study, student self-efficacy can be seen from the student self-efficacy questionnaire for each indicator. For more details, see table 10 below:

Table 10. Self-efficacy Questionnaire for Each Indicator

\begin{tabular}{|c|c|l|c|c|c|c|}
\hline No. & $\begin{array}{c}\text { Self- } \\
\text { Efficiacy }\end{array}$ & $\begin{array}{l}\text { Self-Efficiacy } \\
\text { Indicator }\end{array}$ & $\begin{array}{c}\text { Average } \\
\text { (\%) }\end{array}$ & Category & Average & Category \\
\hline 1 & Level & $\begin{array}{l}\text { Individual } \\
\text { belief in the } \\
\text { ability to level } \\
\text { the difficulty } \\
\text { of the task }\end{array}$ & 76,56 & High & 82,81 & Very High \\
\cline { 2 - 5 } & $\begin{array}{l}\text { Selection of } \\
\text { behavior based } \\
\text { on obstacles or } \\
\text { level of } \\
\text { difficulty of a } \\
\text { task or activity }\end{array}$ & $\begin{array}{l}\text { The level of } \\
\text { strength of an } \\
\text { individual's } \\
\text { belief or } \\
\text { appreciation } \\
\text { for his abilities }\end{array}$ & 87,50 & Very & 91,41 & Very High \\
\hline 2 & Strength & $\begin{array}{l}\text { Individual } \\
\text { belief in the } \\
\text { ability to carry } \\
\text { out tasks in } \\
\text { various } \\
\text { activities }\end{array}$ & 78,91 & High & 84,38 & Very High \\
\hline 3 & Generality & & & \\
\hline
\end{tabular}

From table 10, it is found that the 3rd indicator is the level of strength of belief or individual appreciation of his ability with the highest percentage acquisition of $91.41 \%$, while indicators 1 and 2 are individual confidence in the ability of the level of task difficulty with the lowest gain, namely $82.81 \%$.

\section{Concl usion}

Based on the results of the analysis and discussion in this study, the following conclusions are stated: Online learning-oriented learning tools in improving students' mathematical abstraction abilities and self-efficacy of students developed have met valid criteria. Online learning-oriented learning tools in improving mathematical abstraction abilities and student self-efficacy that have been developed have met practical criteria, namely 1) the response of the team of experts or validators which states that learning tools 
can be used with minor revisions, 2) the average teacher manages learning developed which is in the good category.

Online learning-oriented learning tools in improving students' mathematical abstraction abilities and self-efficacy developed have met the criteria of being effective.

Increasing the students' mathematical abstraction ability to learn using learning tools developed in quadrilateral material, it was obtained that the number of students who got moderate n-gain from the first trial increased to the second trial, namely 14 to 16 people, while for the high category it increased by 5 to 7 people .

The increase in student self-efficacy seen from each indicator of student self-efficacy all increased from trial I to trial II through the results of questionnaires before and after learning.

\section{References}

Ansari, B. I, 2012.Komunikasi Matematikdan Politik. Suatu Perbandingan: Konsep dan Aplikasi. Banda Aceh: Pena.

Arends, R. I. 2008. Learning to Teach, Belajar untuk Mengajar. Edisi Ketujuh. Jilid Satu. (diterjemahkan oleh Soedjipto, Helly, P. dan Soedjipto, Sri, M.) Yogyakarta: Pustaka Pelajar.

Eggen, P. \& Kauchak, D. 2012. Strategi dan Model Pembelajaran Mengajarkan Konten dan Keterampilan Berpikir. Jakarta : Indeks

Iriantara, Y. 2014. Komunikasi Pembelajaran Interaksi Komunikatif dan Edukatif di Dalam Kelas. Bandung: Remaja Rosdakarya.

Minarni, A \& E, Napitupulu. 2017. Developing Instruction Materials Based on Joyful PBL to Improve Students Mathematical Representation Ability. International Education Studies; Vol. 10, No. 9;2017. ISSN 1913-9020 E- ISSN 1913-9039.

Minarni, A. 2013. Pengaruh pembelajaran berbasis masalah terhadap kemampuan,pemahaman, matematis dan ketrampilan social siswa SMP Negeri di Kota banding .Medan; Jurnal Pendidikan Matematika (PARADIKMA) Unimed.

Minarni, A \& E, Napitupulu. 2017. Pembelajaran Matematika Berbasis Joyful ProblemBased Learning.Medan; PUSSIS Unimed.

Ririn, S.D., Perangin-angin, R.B., and Mursid, R. (2020). Development of Multimultural PKN Interactive Learning Multimedia Development in Class IV SD IT NU Tanjung Morawa Academic Year 2018/2019. Budapest International Research and Critics in Linguistics and Education (BirLE) Journal Vol 3 (2): 845-853.

Ritonga, A.A., Susanti, E., and Juanda. (2020). Student Perception Relationships about Teacher and Pedagogy Learning Motivation with Education Learning Results Islamic Religion in SMP Negeri 12 Medan. Budapest International Research and Critics in Linguistics and Education (BirLE) Journal Vol 3 (3): 1564-1569.

Rusman.2011.Model-model pembelajaran Mengembangkan Profesionalisme Guru Edisi Dua.Jakarta : Rajawali Press.

Trianto. 2011. Mendesain Model Pembelajaran Inovatif-Progresif: Konsep, Landasan dan Implementasinya pada Kurikulum Tingkat Satuan Pendidikan (KTSP). Jakarta: Kencana Prenada Media Group.

Thiagarajan, S. Semmel, DS. Semmel, M. 1974. Instructional Development for Training Teachers of Exceptional Children. A Sourse Book. Indiana: Indiana University. 